\title{
MAPPING THE RISK OF FOREST FIRES IN ALGERIA: APPLICATION OF THE FOREST OF GUETARNIA IN WESTERN ALGERIA
}

\author{
BENAMAR BELGHERBI ${ }^{1}$, KHELOUFI BENABDELI ${ }^{1}$, KAMEL MOSTEFAI ${ }^{2}$
}

\begin{abstract}
${ }^{1}$ Research Laboratory in Geo-Environment and Spaces Development, Faculty of Science of Nature and Life, University of Mascara, Mascara 29000, Algeria, BP 305 Sidi Said University of Mascara 29000, Algeria; e-mail: benamar cum@yahoo.fr benabdeli_k@yahoo.fr

${ }^{2}$ Forest Conservation of Mascara, Algeria; e-mail: k.mo@live.fr
\end{abstract}

\begin{abstract}
Belgherbi B., Benabdeli K., Mostefai K.: Mapping the risk forest fires in Algeria: Application of the forest of Guetarnia in Western Algeria. Ekológia (Bratislava), Vol. 37, No. 3, p. 289-300, 2018.

The methods applied in Algeria for the prevention and fight against the fires remain fairly traditional and have proved to be ineffective in reducing the disastrous impact of this phenomenon. However, the aim of this work is to analyse a forest ecosystem that is fairly representative of the whole of the forests in Algeria, on plan risk and vulnerability of the environment for a better control of risk. Using modern geomatics techniques to map the degree of risk of fires and analysis the space: like satellite imagery spatial data and Geographic Information Systems (GIS).The Guetarnia forest in western Algeria has been retained; seven thematic maps have been developed and have helped to develop a sensitivity map to depict the fire risk.
\end{abstract}

Key words: forest fires, map risk, remote sensing, GIS, Guetarnia (Algeria).

\section{Introduction}

Each year, several million hectares were burnt at the global scale in the Mediterranean basin. It is estimated that 6000,000 to 8000,000 ha are annually destroyed by fire, especially in the countries of the northern shore of the Mediterranean (Rowell, Moore, 2000; Carrega, 2008; Hansen et al., 2013). However, the forest of Algeria is typically Mediterranean terms of its climate, terrain, composition and structure; it is very sensitive to fire. Over the centuries, it has witnessed various degradations, while they were flourishing at the Carthage and Roman eras, and even after the invasion of Arabs (De Ribbe, 1866; Trollard, 1893). The forest heritage of Algeria is in perpetual degradation; it is an area estimated at 5 million ha during the colonial period (Boudy, 1948) that has extended to $1,492,000$ ha (FAO, 2013). The forest area was reduced, during the colonial period (1830-1962), to 2,400,000 ha (Boudy, 1948; Berchiche, 1968; Sari, 1978; Rebai, 1983). An average of 18,182 ha is burned annually.

In the MENA (Middle East and North Africa), Algeria represents the country most affected by forest fires in percentage of travelled surface. For a country highly threatened by desertification, it has avery low rate of forestation estimated at 1.76\% (FOSA, 2000; Nedjraoui, 
2003). The analysis of data from the Directorate General of Forests (DGF) pointed out that during the period 1963-2014, the area affected by forest fires was in the order of 1,770,800 ha, or an average of area travelled per year of 35,000 ha/year (DGF, 2014).

The current situation reflects Algeria's weak ability to control the forest fires phenomenon and this is due to several reasons: the lack of a database relating to fire, ignorance of the causes, lack of silvicultural work, aging infrastructure that is most of the time archaic and dilapidated, an absence of vision of management even in the short term; to this should be added a technical staff that is far from any progress in terms of training and current techniques for combating the fires of forests.

The Guetarnia forest is a fair representative of the forests of the country; it is semi-arid, has registered area of 624,286 ha, was burned during the period from 1903 to 1922, and has an annual average of area covered by the fire of $31.02 \mathrm{ha} / \mathrm{year}$. The analysis of the current period (1981-2014), allows seeing that the average of area burned annually is 250 ha on a total of $7,127,707$ ha. The resurgence of fires is clearly confirmed since the annual mean surface area burned has increased from 31 to 250 ha.

Furthermore, the risk assessment of forest fires has been the main topic of several research papers, and fire is the most redoubtable and most devastating factor that can cause damage to the forests of Algeria (Leutreuch, 1982; Benabdeli, 1996; Madoui, 2002; Arafa, 2008; Terras et al., 2008; Khader et al., 2009; Mohamed et al., 2011; Berrichi et al., 2013; Borsali et al., 2014; Meddour et al., 2014; Meddour, 2015). Despite this worrying fact; there is no national strategy focused on mapping the fire risk in order to put in place a plan of prevention is business. Finally, the objective of this study is to use the modern technique geomatics, (GIS), in order to assess the risk of forest fires on the one hand and to put at the disposal of managers a set of adapters that can be used in order to propose a solution for the prevention and management of the forest fire risk. The Guetarnia forest has been chosen, as it brings together the majority of the ecological characteristics and socio-economic of forest ecosystems, to achieve the objectives of the environment for a better control of risk.

\section{Material and methods}

\section{Ecological characterization of Guetarnia forest}

The forest of Guetarnia is located in the north-westerern Algerian region (Fig. 1) and is part of the mountains of Beni-Chougrane. Guetarnia is localized between longitude $0^{\circ} 00$ and $0^{\circ} 30^{\prime} \mathrm{E}$ and latitude $35^{\circ} 00^{\prime} \mathrm{N}$ and $35^{\circ} 30^{\prime} \mathrm{N}$ with an area of $10,140.12$ ha, and also focused between two wilayas, wilaya of Mascara with a surface area of 2,818.82 ha and wilaya of Sidi-Belabbes with 7,321.30 ha. The forest of Guetarnia presents a rugged topography of mountains and foothills with altitude soscillating between 411.8 and $813 \mathrm{~m}$ inducing a class of slope between 15 and 30\% with more than 55\% (Belgherbi, 2002).

The facies lithology is represented by a substrate of origin Miocene and Cretaceous constituted by elements generally soft and eroded. The substratum Miocene is covered everywhere by the quaternary formations: calcareous crusts, sandy clays and sands. The soils are sandy clay to sandy (Dalloni, 1940, 1953). This type of ground limestone, generally low depth (between 30 and $40 \mathrm{~cm}$ ), belonging to the class of redziniferes soils and calcareous brown (Dalloni, 1940, 1953; Belgherbi, 2002).

The forest falls within the bioclimatic floor semi-arid to temperate variant with an average annual precipitation of 350 $\mathrm{mm}$. Two periods characterize this region: a cold season between November and April, recording the minimum of less than $3{ }^{\circ} \mathrm{C}$ and a hot season from May to October with the maxima of $35^{\circ} \mathrm{C}$.

The vegetation, Mediterranean-type sclerophyllous, is characterized by arecovery of the order of $45 \%$ with a composition dominated by three species: the Pinus halepensis Mill, Tetraclinis articulate Vahl and Quercus rotundifolia L. The first two species occupy more than $65 \%$ of the acreage and are pyrophytes with a high combustibility and flammability. The stratum 
shrubby and bushy is represented primarily by the Rosmarinus, Phillyrea and the Chamaerops humilis (Souidi et al., 2010).

\section{Methodology}

The establishments of the map of vulnerability of forests to fires in fact appeal to the application of a model established by (Dagorne, Duche, 1994) and tested on the mountainous forest of the Mediterranean region. The different steps of the methodology adopted throughout in this work are represented by the flowchart synthesized in Fig. 2.

The basic data for these formulas, exploited by a series of specialized software, allow the establishment of different maps (layers of useful information); these last few are going to be the subject of superposition in order to put in place the map from the fire risk. The tools implemented for the development of the map of the fire risk are ENVI 3.4 and MAPINFO 7.0. The latter has been used for the establishment of the digital terrain model (DTM) and for obtaining the map of slopes, exhibitions and the topomorphology.

The ENVI (Environment for Visualising Images) has been used to process the images, enabling the visualization and analysis of data. Its functionality resides in the fact that it contains a library of algorithms, includes functions for transformation of data, filter functions as well as functions of classification.

\section{Fire risk modelling}

To evaluate the fire risk, it is necessary to model each element of risk, three main factors for the assessment of risk of forest fires such as the fuel, the topomorphology and human activities. The index that has interested us in this work is given by formula (1) proposed by (Dagorne, Duche, 1994). The principle of risk estimated by this formula is based on the product of hazard and vulnerability.

$$
I R=5 \cdot I C+2 \cdot I H+I M
$$

where: IR is Risk index; IC is index of combustibility; $I M$ is Topo-morphological index; $I H$ is index of human activities.

Based on the principle of weighted sum, this index is designed as a model assigning each parameter a weighting coefficient based on its influence on the spread of fire.

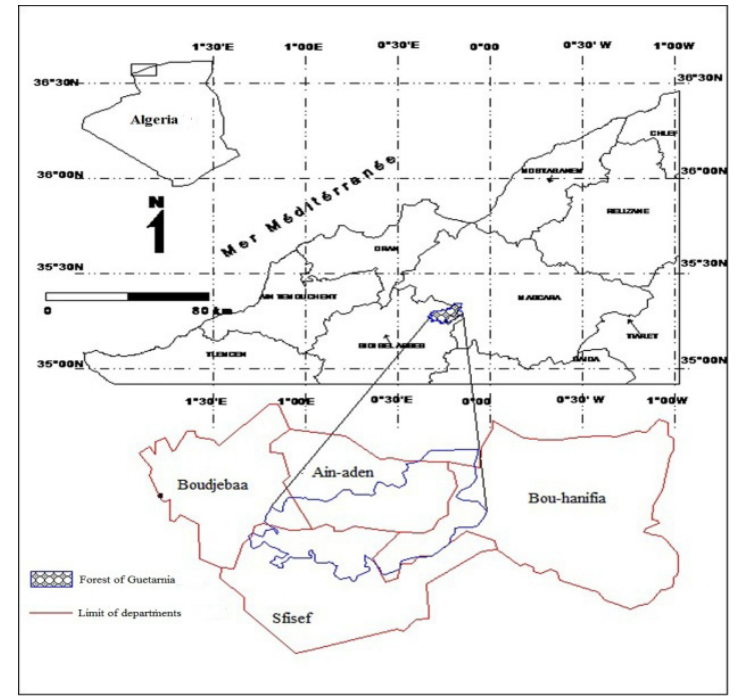

Fig. 1. Location of the forest of Guetarnia.

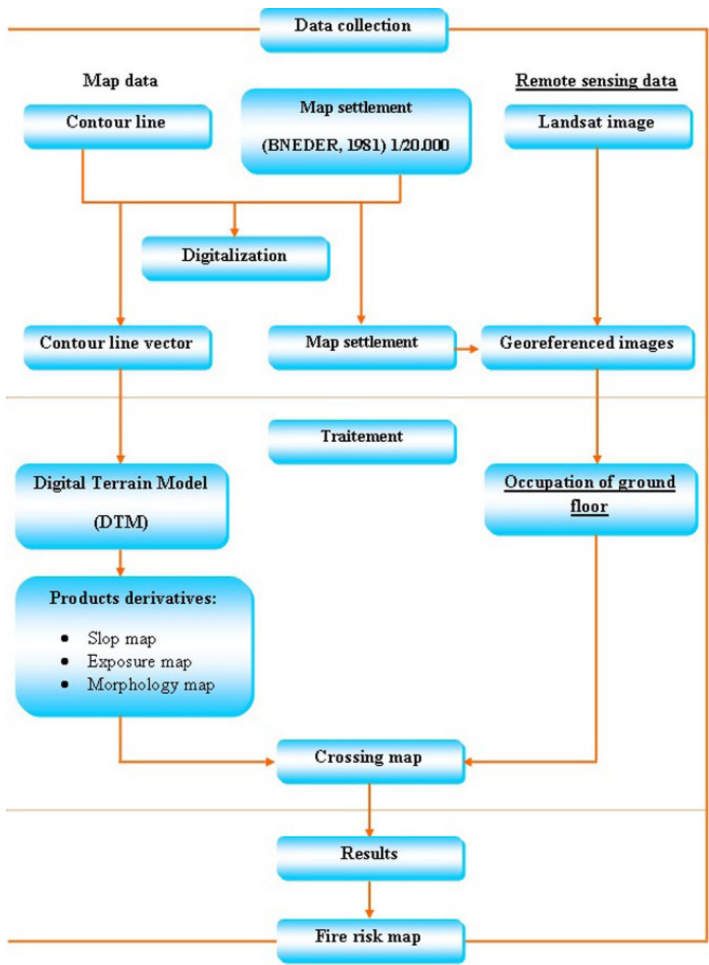

Fig. 2.Graph of establishment process of GIS. 
The characterization of this index is based on the spatial variability of the risk of fire whose determination is the outcome of the physical parameters involved in the model chosen (Keaneet al., 2010).

In the proposed model, index topo-morphologic (IM), three topographic parameters were involved: slope, exposure and altitude. These settings are deducted from the digital terrain model (D.T.M.) in the region. This index is expressed by the following relationship:

$$
I M=3 p+e \cdot m
$$

where: $p$ is slope; $m$ represents morphology of area; $e$ is exposure.

To evaluate the index of combustibility (IC), the method proposed by (Putri et al., 2016) to estimate the potential severity of a fire starting in a forest stand determines has been retained. This method consists of, in the development of a model, empirical data, based on the experience of the fire brigade to weight the terms of a mathematical expression whose parameters are from a standardized description of the vegetation (Keane et al., 2010).

Among the parameters reflecting the susceptibility of the vegetation to fire is the type of fuel available (horizontal stratification and vertical), that is, the phytomasse. This is an important factor in the emergence and spread of fires (Dagorne, Castec, 1992; Mariel, 1998).

The index of combustibility or intensity index of potential fire is expressed by the following relationship:

$$
I C=2.4 B V\left(E_{1}+E_{2}-7.18\right)+39
$$

where: $B V$ is the biovolume of the plant formation; $E_{1}$ is the note of combustibility for wood senior; $E_{2}$ is the note of combustibility for the wood bottom or herbaceous plants.

The biovolume of the vegetation formation is obtained by adding the rate of recovery of each of the 4 strata of vegetation (wood senior, wood bottom, herbaceous and litter) to which we add the rate of recovery of snags and dead wood, if there is a place. Each of these recovery rates is 0 (absence of stratum) and 10 (stratum forming a closed canopy); the biovolume is therefore between 0 and 50. The notes of calorie intensity are included between 1 and 8 for the two dominant species: $E_{1}$ for wood senior and $E_{2}$ for wood bottom or herbaceous.

\section{Results}

\section{The digital terrain model (DTM)}

The forest of Guetarnia presents a rugged topography with a mountainous area located in the south of the forest and stretching toward the north-east. The lands at low altitude are local-

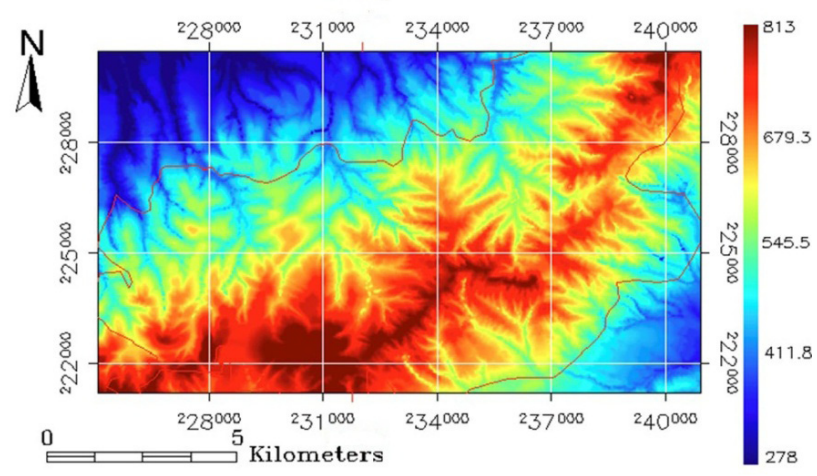

Fig. 3. Digital terrain model. ized in the northern part of the forest. The mountainous part has an altitude that varies between 650 and $813 \mathrm{~m}$; it is dominant at the level of Sidi Bel-Abbes at the level of the canton of Ain Aden and Sfisef (Fig. 3).

The digital terrain model (DTM) allows you to derive slope, exposure, and topomorphology; these derivatives are used to calculate the index topomorphologic. 
Map of exposure

The forest massif of Guetarnia presents three major classes of exposure in relation with the prevailing winds, as listed in Table 1.

The exposure " $e$ " reflects the situation of the catchment area in relation to the prevailing winds and to the solar radiation. The map of the exposure of the forest is represented by the Fig. 4 below.

\section{Map of topomorphology}

The position in the catchment area or topomorphology “ " $m$ ”" weighted the fire intensity as a function of the position in the terrain. Topomorphology was adopted in preference to altimetry. To do this, four main sets of topomorphologic were retained in (Table 2; Fig. 5). The four classes define the topographic situations increasingly unfavourable for the fight (Belgherbi, 2002).

The forest of Guetarnia is represented by the senior foothills on an area of $6,510.36$ ha (62.20\%); the fraction mountain represents only an area of $1,433.05$ ha (14.13\%).

\section{Map of slopes}

The slope " $p$ " is a factor of the acceleration of fire front. It is classified into four classes.
T a ble 1. Frequency of exposures.

\begin{tabular}{|l|c|c|}
\hline Meaning & Area (ha) & Percentage (\%) \\
\hline NE-E-SE-S & $4,053.37$ & 39.97 \\
\hline S-SW-W-NW & $3,992.66$ & 39.37 \\
\hline NW-N-NE & $2,094.59$ & 20.65 \\
\hline Total & $\mathbf{1 0 , 1 4 0 . 1 2}$ & $\mathbf{1 0 0}$ \\
\hline
\end{tabular}

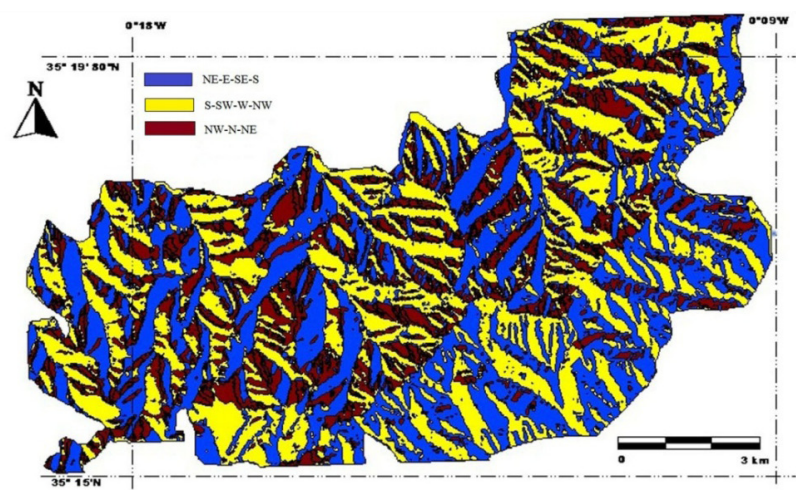

Fig. 4. Map of exposure.

T a b le 2. Frequency of the topomorphology.

\begin{tabular}{|l|c|c|}
\hline Meaning & Area (ha) & Percentage (\%) \\
\hline $\mathrm{P}<3 \%$ (Plain) & 83.93 & 0.83 \\
\hline $\mathrm{P}(3-12.5 \%)$ (Lower piedmont) & $2,112.78$ & 20.84 \\
\hline $\mathrm{P}(12.5-25 \%)$ (High piedmont) & $6,510.36$ & 64.20 \\
\hline $\mathrm{P}>25 \%$ (Mountain) & $1,433.05$ & 14.13 \\
\hline Total & $\mathbf{1 0 , 1 4 0 . 1 2}$ & $\mathbf{1 0 0}$ \\
\hline
\end{tabular}

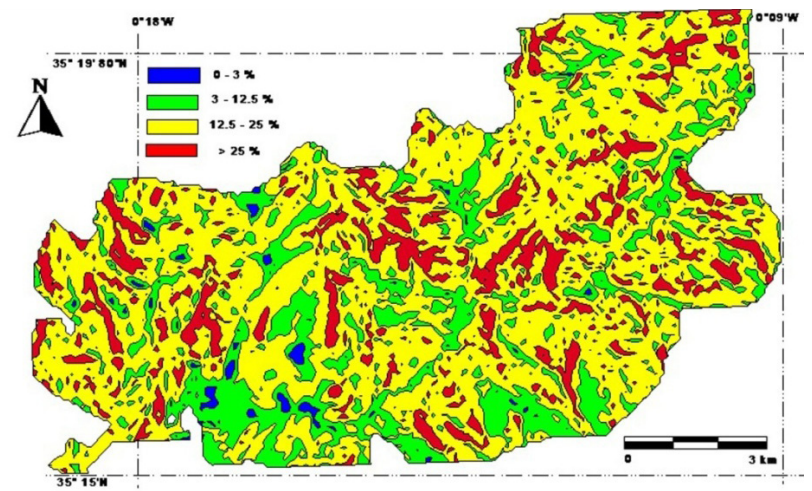

Fig. 5. Map of topomorphologic. 


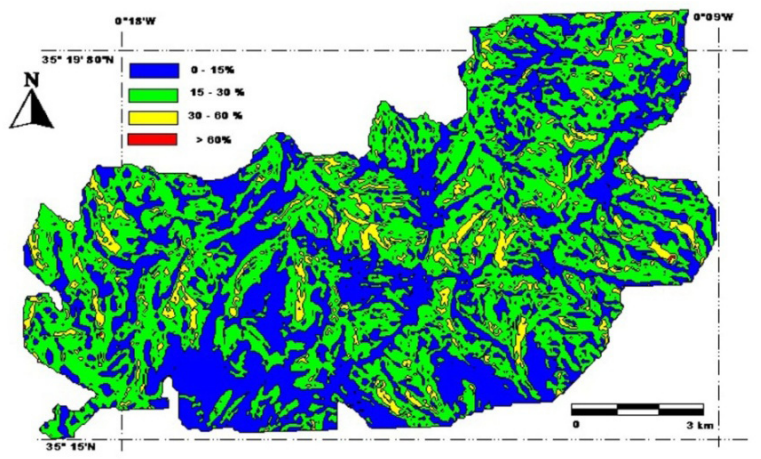

Fig. 6. Map of slopes.

T a b l e 3. Frequency of slopes.

\begin{tabular}{|l|c|c|}
\hline Class of slope & Area (ha) & Rate (\%) \\
\hline$<15 \%$ & $3,844.12$ & 37.91 \\
\hline $15 \%<\mathrm{P}<30 \%$ & $5,606.47$ & 55.29 \\
\hline $30 \%<\mathrm{P}<60 \%$ & 687.50 & 6.78 \\
\hline$>60 \%$ & 2.03 & 0.02 \\
\hline Total & $\mathbf{1 0 , 1 4 0 . 1 2}$ & $\mathbf{1 0 0}$ \\
\hline
\end{tabular}

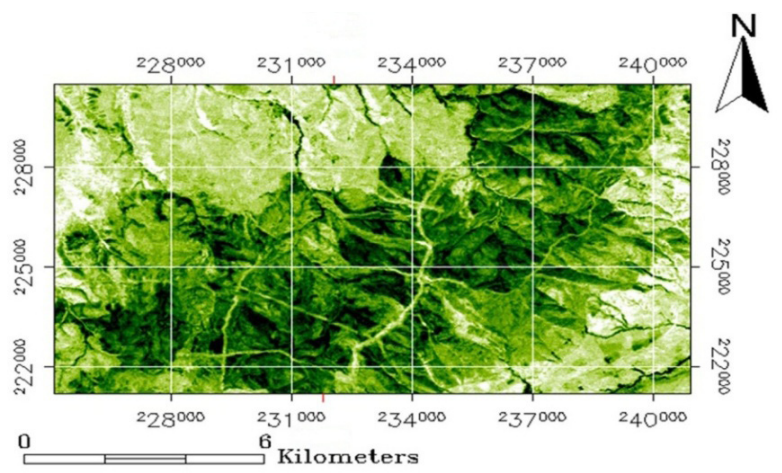

Fig. 7. Map of the NDVI.
The threshold selected, for each class, takes into account the possibilities of executions of forest work (Dagorne, Duche, 1994). The map of slopes obtained is represented by Fig. 6. The classes of average and steep slopes are most dominant with more than $62 \%$. The different percentages of the four classes are summarized in Table 3.

Map of vegetation index
(NDVI)

As per the requirements of the study, a vegetation index was calculated from a combination of red tape and nearinfra-red in the image Landsat ETM+. This index is used to discriminate the two components of ecosystem: soil and plants on one hand and to calculate the biovolume of the forest on other hand. The formula used to calculate NDVI is given by following equation:

$N D V I=P I R-(R / P I R)+R(4)$

where: PIR is the band nearinfra-red and $R$ is the red band. The card that is extracted by the application of the vegetation index (NDVI) is represented in Fig. 7.

\section{Map of occupation of ground}

The map of occupation of the forest floor of Guetarnia is dominated by the formations of Pinus halepensis at $40.91 \%$, Tetraclinis articulate at $26.73 \%$ and Quercus rotundifolia at a 
rate of $22.34 \%$, and finally, to bare soil and agricultural enclaves in the order of $10.02 \%$. This map highlights the clear dominance of coniferous formations, which were close to $67.64 \%$ of the area of the forest and increase the risk of triggering the fires, we have presented in the form of Table 4 and Fig. 8.

\section{Exploitation of results}

The risk assessment is necessary to model each of the elements of risk. The first step is to select the parameters specific to each element (slope, exposure, topomorphology and settlements) and then to use the mode of representation of the risk in order to evaluate. The parameters are the factors of the natural environment and anthropogenic that influences the outbreak, the spread and the intensity of fire, as well as its conduct (aspects related to the fight). The second step based on the intersection of thematic layers by application of the formulas cited previously. The human factor is characterized by the occupation of space, since the forest is not inhabited and is located for enough away from the houses; the human index is equal to zero.

\section{Evaluation of the index of combustibility}

The map of index of combustibility, as shown in Fig. 9, has been achieved from the crossing junction of vegetation index layer and occupation layer of the soil. The biovolume was
T a b l e 4. The distribution of species.

\begin{tabular}{|l|c|c|}
\hline Meaning & Area (ha) & Rate (\%) \\
\hline Pinus halepensis & $4,148.83$ & 40.91 \\
\hline Tetraclinis articulata & $2,710.24$ & 26.73 \\
\hline Quercus rotundifolia & $2,265.36$ & 22.34 \\
\hline Bare Soil & $1,015.69$ & 10.02 \\
\hline Total & $\mathbf{1 0 , 1 4 0 . 1 2}$ & $\mathbf{1 0 0}$ \\
\hline
\end{tabular}

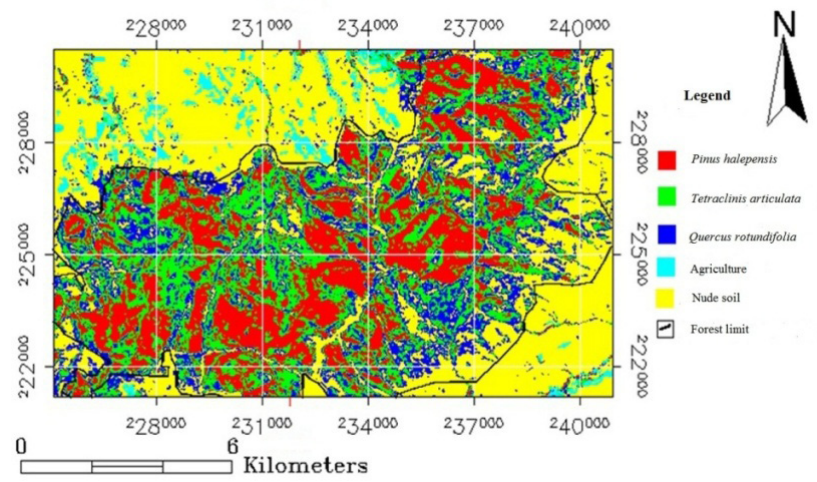

Fig. 8. Map of the occupation of the ground.

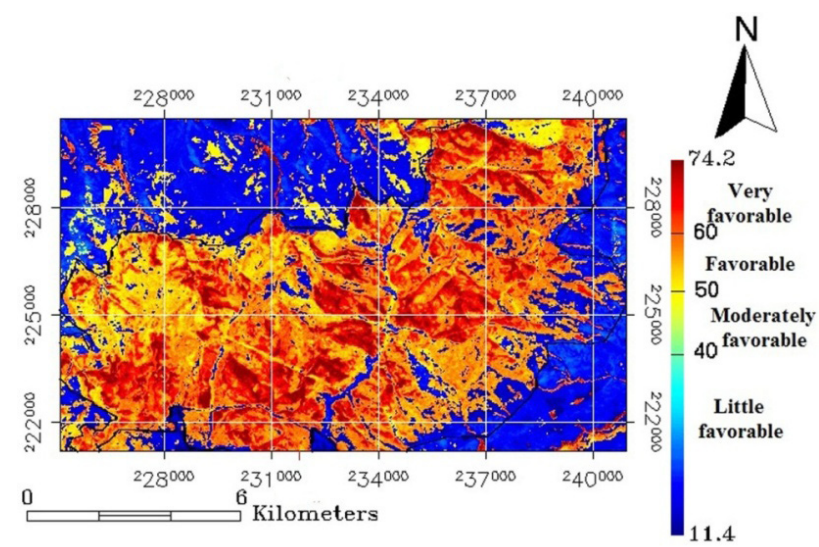

Fig. 9. Map of the index of combustibility. 
T a b l e 5. Notes of caloric species (CEMAGREF, 1989).

\begin{tabular}{|l|c|c|c|}
\hline Tree Species & Note calorific value & $\begin{array}{c}\text { Shrubby Species } \\
\text { Or herbaceous species }\end{array}$ & Note calorific value \\
\hline Pinus halepensis & 8 & Rosmarinus & 5 \\
\hline Tetraclinis articulata & 7 & Phyllerea & 5 \\
\hline Quercus rotundifolia & 7 & & \\
\hline Bare Soil & -- & -- & -- \\
\hline
\end{tabular}

T a b l e 6. Indices of combustibility.

\begin{tabular}{|l|c|c|}
\hline Class & Area (ha) & Rate (\%) \\
\hline IC $<40$ & $1,819.33$ & 17.94 \\
\hline $40<$ IC $<50$ & $1,234.88$ & 12.18 \\
\hline $50<$ IC $<60$ & $6,632.63$ & 65.41 \\
\hline IC $>60$ & 453.28 & 4.47 \\
\hline Total & $\mathbf{1 0 , 1 4 0 . 1 2}$ & $\mathbf{1 0 0}$ \\
\hline
\end{tabular}

calculated from the layer of vegetation index, but against the notes of calorie intensity $\left(\mathrm{E}_{1}\right.$ and $\left.\mathrm{E}_{2}\right)$ that have been extracted from the layer of occupation of the ground (Table 5). The two notes caloric of species present in the Guetarnia forest are those established by (Dagorne, and Castec, (1992) ; and Colin et al., (2001) with the exception of Tetraclinis articulate, which has been equated with the closest species Juniperus (CEMAGREF, 1989).

The values of index of combustibility, took into consideration, four classes ranging from a low rating, medium, high and very high (Table 6).

More than $70 \%$ of the surface area of the forest of Guetarnia is located in 'hight' and 'very hight' classes of index of combustibility; the rest is between 'low' and 'medium' severity with values respectively 17.94 and $12.18 \%$. This index typically represents bare soils and areas of low vegetation density (Fig. 9).

\section{Evaluation of the topomorphologic index}

The topomorphologic index is obtained by a combination of three criteria (slope, exposure and topomorphology), using the following formula:

$$
I M=3 p+e \cdot m
$$

where: $p$ is slope (coded between 1 and 4 ), $\div e \div$ is exposure (coded 0 to 3 ), and $m \div$ represents the morphology of the area (coded of 1 to 4 ).

This index is a factor in the calculation of risk index, depending on the topographic situation and of the exhibition encountered, aggravating more or less the spread and power of the fire. The results obtained allow us to get four classes of topomorphologic, summarized according to their importance in the Table 7.

Nearly $52 \%$ of the surface area of the forest of Guetarnia is located in the conditions topomorphologic little favourable to fire accentuation. The conditions moderately favourable to fire risk cover the surface area of $44.63 \%$, and only $4 \%$ is in the range very favourable (Fig. 10). 
The topomorphologic index moderately favourable to very favourable represents fractions of high slopes and steep. The slope influences the spread of fire; it accelerates its speed in the catchment area and then, it slows down (Traubaud, 1979; Missoumi, Tadjraoui, 2003).

\section{Evaluation of fire risk index}

The evaluation of fire risk index is the result of intersection between the layer of combustibility index and the layer of topomorphologic index. The index is given by the following formula:

$$
I R=5 \cdot I C+I M
$$

where: $I R$ is the Risk index, $I C$ is the index of combustibility and $I M$ is the topomorphological index.

The forest of Guetarnia is located in medium to strong risk index, covering an area of $8,189.17$ ha or $80.76 \%$. The low risk remains fairly high with a rate of $18.48 \%$; and the resth is barely $1 \%$, is very great danger as the confirmed by the rates as shown in the Table 8 and Fig. 11.

\section{Discussion}

The forest of Guetarnia, share its floristic composition diversified, a vegetation density
$\mathrm{T}$ a b l e 7. The classes of the index topomorphologic.

\begin{tabular}{|l|c|c|}
\hline Classes & Area (ha) & Percentage (\%) \\
\hline $\mathrm{M}<9$ (little favourable) & $5,253.53$ & 51.81 \\
\hline $9<\mathrm{IM}<14$ (moderately favourable) & $2,586.40$ & 25.50 \\
\hline $14<\mathrm{IM}<19$ (favourable) & $1,939.46$ & 19.13 \\
\hline $\mathrm{IM}>19$ (very favourable) & 360.73 & 3.56 \\
\hline Total & $\mathbf{1 0 , 1 4 0 . 1 2}$ & $\mathbf{1 0 0}$ \\
\hline
\end{tabular}

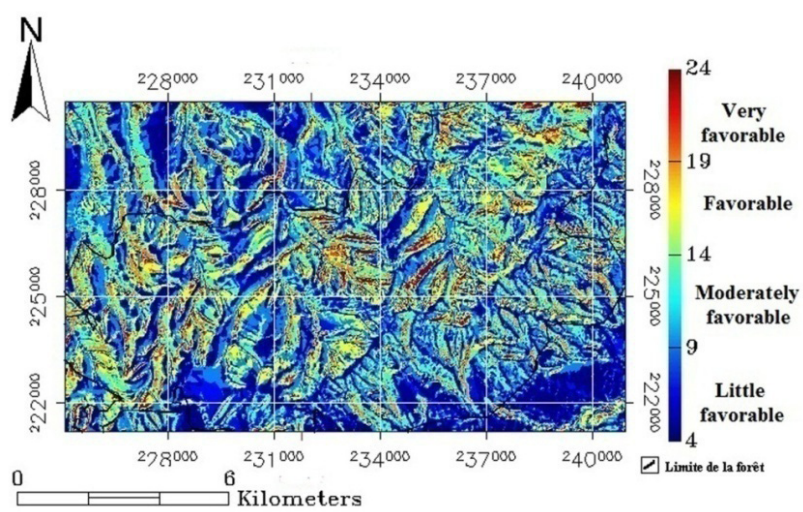

Fig.10. Map of the indextopomorphologic.

T a b l e 8. Indices of fire risk.

\begin{tabular}{|l|c|c|}
\hline Class & Area (ha) & Percentage (\%) \\
\hline $\mathrm{IM}<18$ (low risk) & $1,873.52$ & 18.48 \\
\hline $18<\mathrm{IM}<27$ (medium risk) & $5,748.61$ & 56.69 \\
\hline $27<\mathrm{IM}<36$ (high risk) & $2,440.56$ & 24.07 \\
\hline $\mathrm{IM}>36$ (risk very hard) & 77,44 & 0.76 \\
\hline Total & $\mathbf{1 0 . 1 4 0 , 1 2}$ & $\mathbf{1 0 0}$ \\
\hline
\end{tabular}

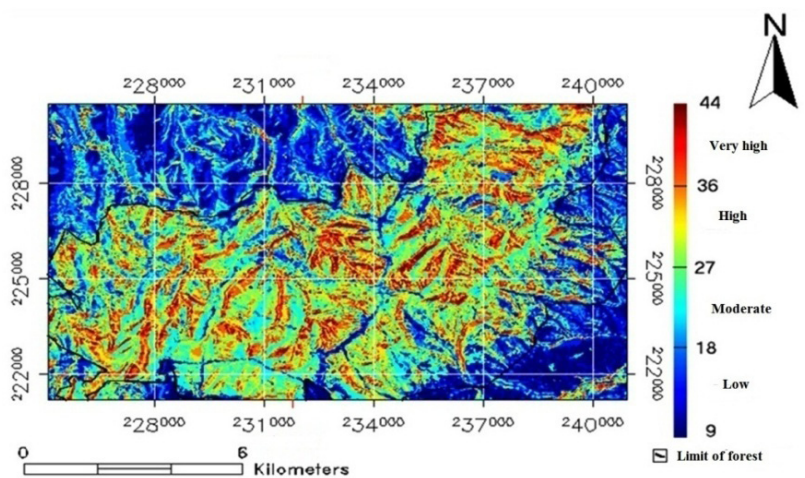

Fig. 11. Map of the index of fire risk. 
strong enough and a presence of woody species including the combustibility and flammability are very high is classified in terms of vulnerability to fire risk between medium and high.

The composition and structure of forest stands, in this case the vertical and horizontal distribution of species, determine their flammability and combustibility, and conditioning the process of putting to fire and the power with which the fire is going to maintain and spread (Colin et al., 2001).

Some plant species are more vulnerable to fire than others. The significant presence of the Pinus halepensis Mill; the species qualified as being the most flammable and combustible of Mediterranean forests (Velez, 1994; Ramade, 1997; Dimitrakopoulos, Mitsopoulos, 2006); in space and in density determines the high risk of fire of the drill bit.

The matorral is more willing to be damaged by the lights as the forest formations are wooded. This situation is explained quite easily by the difference in the composition of these formations and by the climatic conditions to which they are subjected to. The predisposition of the plant formations to fire is, in effect, related to a large extent to their water content. The latter is strongly influenced by the general conditions of drought (temperature and dryness of the air, lack of precipitation, and episodes of winds dry and violent). These conditions of predisposition are not constant in time. They evolve, for example, according to the state of vegetation, which is the result of both its natural dynamics; forestry is applied to it and of the potential passages of the fire (Assali et al., 2016).

In addition, conditions such as topomorphologic, slope and exposure, which determine the factors that are conducive to triggers and enhance the forest fires. From the point of view of biophysics, the expression of fire in a natural space is a function of its environment, including, of course, climate, the nature of the terrain and the fuel present in the area concerned (Pyne et al., 1996). Therefore, the spatial models that simulate the behaviour of fire, often use as input data the variables measured as altitude, slope, exposure, weather and vegetation (Anderson, 1982; Andrews et al., 2005). These factors are at the origin of the outbreak of the fire and its rapid spread. For example, the angle of slope affects the moisture and conservation of the soil, which in turn affects the distribution of vegetation and its composition, and as a result, the characteristics of the fuel and its flammability (Franklin, 1998).

In effect, the biophysical factors that influence the outbreak of fire and its spread can produce multiple consequences, direct and indirect, on the regime of fire (Whelan, 1995)

This index of risk of lights high enough for the forest of Guetarnia is also the result of almost total lack of silvicultural work and planning. The forest is currently composed of young stands following the escalation of lights on one hand and to high frequency and very close to the lights.

\section{Conclusion}

Despite the importance of the phenomenon of forest fires in Algeria, the causes of these fires are still unknown, which complicates any prevention plan. The analysis of information relating to forest fires has revealed that more than $90 \%$ of the causes are listed as unknown. The strategy for the management of risk of forest fires in Algeria is support on the intervention where as the techniques having done their evidence are based mostly on forecasts and 
prevention. However, the forest fires cannot be minimized through prevention, which rests on risk assessment. The map of vulnerability of the forest fires extracted from the forest of Guetarnia shows a model of application of remote sensing and GIS that can be generalized on the forest ecosystems closely, enough. Moreover, the risk map carried out allows demonstratingthe severity of risk incurred following the outbreak of fires from the physical factors (topomorphology, slope and exposure) and biological (vegetation).Thus, it allows to orient the managers in the field of forest fire fighting and to locate the means of intervention for rapid action in time and space.

\section{References}

Anderson, H.E. (1982). Aids to Determining Fuel Models for Estimating Fire Behavior. USDA Forest Service, Intermountain Research Station, General Technical Report INT-167.

Andrews, P.L., Bevins, C.D. \& Seli R.C. (2005). Behave Plus Fire Modeling System, version 3.0: user's guide. USDA Forest Service, Rocky Mountain Research Station, General Technical Report RMRS-GTR-106WWW Revised.

Arafa, A. (2008). Les incendies de forêt en Algérie : Stratégies de prévention et plans De gestion. Thèse doctorat, université de Constantine, Algérie.

Assali, F., Rouchdi, M., Ajerame, M.,Lahlou, M. \& Mharzi H. (2016).Cartographie du risqued'incendies de forêtdans la région de Chefchaouen-Ouazzane (Maroc). Revue. Mar. Sci. Agron. Vét., 4(2), 5-22.

Belgherbi, B. (2002). Intégration des données de télédétection et des données multisources dans un système d'information géographique (SIG) pour la protection des forêts contre les incendies (cas de la forêt de Guetarnia-Ouest d'Algérie). Thèse, Université de Tlemcen, Algérie.

Benabdeli, K. (1996). Aspects physionomico-structuraux de la végétation ligneuses forestières face aux pressions anthropozoogènes dans les monts de Dhaya et les monts de Tlemcen. Thèse doctorat, Université d'Aix-Marseille III, France.

Berchiche, T. (1968).Contribution à létude socio-économique de la forêt algérienne. Thèse d’agronomie, INA Alger, Algérie.

Berrichi, M., Benabdeli, K. \& Leutreuch B.N. (2013). Feux de forêts en Algérie : entre points de vue des écoliers et politique de la prévention. Mediterranea, ÉpocaII, 24,132-159. DOI: 10.14198/MDTRRA2013.24.05.

Borsali A.H., Benabdeli, K. \& Gros R. (2014). Dynamique structurelle de la végétation en zone semi-aride : cas de la forêt de Fénouane (monts de Saida, Algérie occidentale). Afrique Science, 10(2), 419-433. www.afriquescience. info.

Boudy, P. (1948). Economie forestière Nord-Africaine. Paris:Larose.

Carrega, P. (2008). Le risque d'incendies de forêt en région méditerranéenne: compréhension et évolution. Actes des colloques de l'AIC, 9-13 septembre 2008 (pp. 11-23). Montpellier.

CEMAGREF (1989). Guide technique du forestier méditerranéen français, protection des forêts contre les incendies. Edition Quae, France.

Colin, P.Y., Jappiot, M., Mariel, A., Cabaret, C., Veillon, S. \& Brocchiero F. (2001). Protection des forêts contre l'incendie: fiches techniques pour les pays du bassin méditerranéen. FAO conservation, IRNAE, CEMAGREF, MAPA.

Dagorne, A. \& Castec J.M. (1992).Gestion des espaces forestiers en zones rouges. Finisterra, 27(54), 141-166. DOI: $10.18055 /$ Finis 1884 .

Dagorne, A. \& Duche A. (1994). Protection des forêts contre les incendies et Système d'information géographique: Application à la commune d'Auribeau sur Siagne (Alpes Maritimes). Forêt Méditerranéenne, 25(4), 416-419.

Dalloni, M. (1940). Note sur la classification du Pliocène supérieur et du Quaternaire de l'Algérie. Bulletin de la Société de Géographie et d'Archéologie, 8-43.

Dalloni, M. (1953). La limite du Tertiaire et du Quaternaire dans le nord-ouest de l'Algérie et des contrées voisines. ActeIV ${ }^{e}$ Congrès International Quatrenaire, 1,19-28.

De Ribbe, Ch. (1866). La question des incendies de forêts dans l'Algérie et dans les aures de la Provence. Revue AgroForestière, 201-213.

DGF (2014). Situation des forêts algériennes vis-à-vis les incendies et les feux de forêts.

Dimitrakopoulos, A.P. \& Mitsopoulos K. (2006). Global forest resources assessment 2005. Report on fires in the Mediterranean Region. Working paper FM/8/E, Forestry Department. Rome: FAO. 
FAO (2013). Etat des forêts méditerranéennes. Italie: FAO.

FOSA (2000). Létude prospective du secteur forestier en Afrique. Italie: FAO.

Franklin, J. (1998). Predicting the distribution of shrub species in Southern California from climate and terrainderived variables. Journal of Vegetation Science, 9, 733-748. DOI: 10.2307/3237291.

Hansen, M.C., Potapov, P.V., Moore, R., Hancher, M., Turubanova, S.A., Tyukavina, A., Thau, D., Stehman, S.V., Goetz, S.J., Loveland, T.R., Kommareddy, A., Egorov, A., Chini, L., Justice, C.O. \& Townshend J.R. (2013). High-resolution global maps of 21st-century forest cover change. Science, 342, 850-853. DOI: 10.1126/science.1244693.

Keane, R.E., Drury, S.A., Karau, E.C., Hessburg, P.F. \& Reynolds K.M. (2010). A method for mapping fire hazard and risk across multiple scales and its application in fire management. Ecological Modelling, 221(1), 2-18. DOI: 10.1016/j.ecolmodel.2008.10.022.

Khader, M., Benabdeli, K., Mederbal K., Fekir, K., Gueddim, R. \& Mekkous B. (2009). Etude du risque incendie à l'aide de la géomatique cas de la forêt de Nesmoth (Algérie). Mediterránea, 20, 205-234. DOI: 10.14198/ MDTRRA2009.20.07.

Leutreuch, B.N. (1982). Le reboisement en Algérie et ses perspectives d'avenir. Thèse doctorat, Université de Gembloux, Belgique.

Madoui, A. (2002). Les incendies de forêt en Algérie: Historique, bilan et analyse. Forêt Méditerranéenne, 23, 23-30.

Mariel, A. (1998). Evaluation et cartographie du risque d'incendie de forêt vers une Application sur le massif des Maures (sud-est de la France), à l'échelle des PPR. Ingénierie, 105-114.

Meddour, O.S., Meddour, R., Vittorio, L. \& Derridj A. (2014).Motifs des incendies de forêt en Algérie : analyse comparée des dires d'experts de la Protection Civile et des Forestiers par la méthode Delphi. Vertigo, 14 (3). DOI: $10.4000 /$ vertigo. 15462 .

Meddour, O.S. (2015). Wildfires in Algeria: problems and challenges. iForest-Biogeosciences and Forestry, 8, 818-826. DOI: 10.3832/ifor1279-007.

Missoumi, A. \& Tadjerouni K. (2003). Apport SIG et imagerie Alsat1 pour la cartographie des risques d'incendie de forêt. $2^{\text {nd }}$ FIG Regional Conference, 2-5 December 2003, Marrakech, Morocco.

Mohamed, S.G., Amar, D., Makhlouf, B., Bounif, A., Mostefa, G. \& Amar B. (2011). A fire risk modelling and spatialization by GIS - application on the forest of Bouzareah Clump, Algiers (Algeria). Journal of Geographic Information System, 3, 254-265. DOI: 10.4236/jgis.2011.33022.

Nedjraoui, D. (2003). Profil fourrager. Italie: FAO.

Putri, A., Lilik, B.P. \& Siti B.R. (2016). Forest fire vulnerability mapping in Way Kambas National Park. Procedia Environmental Sciences, 33, 239-252. DOI: 10.1016/j.proenv.2016.03.075.

Pyne, S.J., Andrews, P.L. \& Laven R.D. (1996). Introduction to wildland fire. NewYork: Wiley.

Ramade, F. (1997).Conservation des écosystèmes méditerranéens: enjeux et prospective. Paris.

Rebai, A. (1983). Les incendies de forêts dans la wilaya de Mostaganem (Algérie): étude écologique et proposition d'aménagement. Thèse doctorat, Université de Science Marseille, France.

Rowell, A. \& Moore P.F. (2000). Global review of forest fires. Gland:WWF/IUCN.

Sari, D. (1978). Le déboisement de l'Algérie. Doc CNRS, 17, 102-164.

Souidi, Z., Hamimed, A., Donze, F., Seddini, A. \& Mederal K. (2010). Estimation de l'évapotranspiration d'un couvert forestier en Algérie par télédétection. Télédétection, 9 (3-4), 164-181.

Terras, M., Benabdeli, K. \& Labani A. (2008). Dynamique phytoécologique du Thuya de Berberie face à l'incendie. Forêt Méditerranéenne, 29, 33-40.

Traubaud, L. (1979). Les feux des forêts: mécanismes, comportement et environment. Ed Aubervilliers, France.

Trollard, P. (1893). La colonisation et la question forestière. Paris: Larose.

Velez, R. (1994). La protection contre les incendies de forêts: principes et méthodes d’action. Options Méditerranéennes, 26, 1-18.

Whelan, R.J. (1995). The ecology of fire. Cambridge: Cambridge University Press. 